\title{
Effect of different nitrogen levels on some soil characteristics and chemical composition of wheat plant (Triticum aestivium L.)
}

\author{
Abdeen S.A. ${ }^{*}$, S. M. El-Hamamsy ${ }^{2}$ and M.A. Hager ${ }^{3}$ \\ 1- Department of Soils and Water, Faculty of Agriculture, Al-Azhar University, Cairo, Egypt. \\ 2- Department of Biochemistry, Faculty of Agriculture, Al-Azhar University, Cairo, Egypt. \\ 3- Department of Agronomy, Faculty of Agriculture, Al-Azhar University, Cairo, Egypt. \\ *Corresponding Author: sayed_abdrahman@yahoo.com
}

\begin{abstract}
A field experiment was carried out at Faculty of Agriculture, Al-Azhar Univ., Nasr City, Cairo, Egypt, to investigate the effect of different nitrogen levels on some soil characteristics and chemical composition of wheat crop. To achieve this task two varieties"Gemmeiza7 and Gemmeiza 9" of wheat plant were studied under five nitrogen levels (i.e. 0, 65, 130, 195 and 260 $\mathrm{kg} / \mathrm{fed})$ were applied as urea $(46 \% \mathrm{~N})$ as nitrogen fertilizer. All the plots were fertilized with super phosphate and $\mathrm{K}$ - sulfate according to the general recommendation dose of Ministry of Agriculture. Results indicated that soil organic matter, EC and soil porosity were increased with increasing the rate of nitrogen application. But $\mathrm{pH}$ and the bulk density were decreased significantly. Application of $260 \mathrm{~kg} \mathrm{~N} / \mathrm{fed}$ gave the highest values of NP and K contents in straw and grain compared to control treatment. The percentages of $\mathrm{N}$ and $\mathrm{K}$ increased significantly by increasing Nitrogen rate up to $260 \mathrm{~kg} \mathrm{~N} / \mathrm{fed}$. But $195 \mathrm{Kg} / \mathrm{fed}$ gave the highest values of $\mathrm{p}$ in grains in the two cultivars. On the other hand, chemical composition (crude protein, total carbohydrates, lipids, moisture, ash and fiber) of two wheat varieties was affected by the addition of nitrogen rates. The crude protein percentage was increased significantly by increasing the rate of nitrogen application. Also the total number band of Protein electrophoretic increased with increasing the nitrogen levels compared with control. In most cases lipids were decreased with increasing the rate of nitrogen. But fiber was increased. Total carbohydrate was significantly decreased with increasing of nitrogen rate. Also the highest value of moisture percentage was observed in $65 \mathrm{Kg} / \mathrm{fed}$ treatment in the two cultivars. Generally, Gemmeiza 7 was higher than Gemmeiza 9 of Protein percentage at the same dose of nitrogen levels.
\end{abstract}

Key words: Nitrogen levels, soil characteristics, chemical composition. Wheat (Triticum aestivium L.).

\section{INTRODUCTION}

Fertilizer inputs can affect the physical and chemical characteristics of the soil, in addition to increasing the content of nitrate in soil, leads to changes in soil $\mathrm{pH}$ and many other soil properties. Low soil fertility, especially nitrogen $(\mathrm{N})$ deficiency, is one of the major constraints limiting wheat production ${ }^{(1)}$. Thus, increased usage of $\mathrm{N}$ fertilizer is considered to be a primary means of increasing wheat grain yield and protein content. Nitrogen is a primary constituent of grain protein, wheat of a high percentage protein is produced only where the crop is provided with an adequate nitrogen supply. The economic value of wheat production is determined by the grain protein content. Decrease of the protein value in wheat about normal level has obvious economic consequences for our country. So the high fertile soil is an essential 


\begin{abstract}
Abdeen S.A. et al.
ingredient for producing high quality wheat ${ }^{(2)}$.The fertilizer plays a significant role towards the quality of grain. The increasing of nitrogen dose led to increase the crude protein, fodder and dry matter yield in forage sorghum. They also mentioned that plant nutrition may not only affect the forage production, but also improve the quality of forage through of its protein contents ${ }^{(3)}$. The production of bread quality wheat is possible through correct fertilizer treatment. The wheat quality is affected by genotype and environment, fertilizer treatments and post harvest conditions. Nitrogen significantly affected the protein contents and other quality characteristics such as loaf volume, grain and texture score of bread ${ }^{(4)}$. Nitrogen is one of the main inputs of the winter wheat crop (Triticum aestivum L.) in Egypt. If there is no enough amount of nitrogen fertilizer, the yield and quality of wheat will become worse.

Nutrition is essential for plant life and yield therefore, mineral fertilization is a common agronomic practice that leads to improve productivity, but with the steadily increased prices of chemical fertilizer, especially nitrogen fertilizer and the pollution problems of soil and water ${ }^{(5)}$. High wheat yields require increases in $\mathrm{N}$ application and the excessive addition of this nutrient can contribute to watercourse pollution. Cereal producers are under pressure to increase their yields and maintain their profitability despite a group of environmental restrictions and high fertilizer costs ${ }^{(6)}$.

Wheat (Triticum aestivum, L.) is one of the most important crops used in human food and animal feed in Egypt. Recently a great attention of several investigations has been directed to increase the productivity of wheat to minimize the gap between the Egyptian production and consumption by increasing the cultivated area, and wheat yield per unit area ${ }^{(7)}$. Wheat provides more protein than any other cereal crops ${ }^{(8)}$. However, the global challenge for wheat nutrition is to increase grain yield while maintaining its $\operatorname{protein}^{(9)}$. Nitrogen $(\mathrm{N})$ is an essential nutrient for plant growth and is a key limiting factor in agro ecosystems. Nitrogen is a constituent of amino acids, which are required to synthesize proteins and other related compounds. It plays a role in almost all plant metabolic processes ${ }^{(10)}$. In addition, more and more application of $\mathrm{N}$ fertilizer caused pollution of groundwater and other problems ${ }^{(11)}$. This study aims to investigate the effect of nitrogen different levels on some soil characteristics and chemical composition of wheat crop.
\end{abstract}

\title{
MATERIALS AND METHODS
}

A field experiment was conducted at the farm of Faculty of Agriculture, Al- Azhar University, Nasr City Cairo Egypt, during the winter of season 2015 to investigate the effect of different nitrogen levels on some soil properties and chemical composition of wheat varieties "Gemmeiza 7 and Gemmeiza 9". Wheat varieties were obtained from Field Crops Research Institute. The experiment was laid out in a randomized complete block design in factorial arrangement with three replications. The net unit area of experimental plot was $9.0 \mathrm{~m}^{2}(3 \times 3 \mathrm{~m})$. Five nitrogen levels (i.e. 0, 65, 130, 195 and $260 \mathrm{~kg} / \mathrm{fed})$ were applied with urea $(46 \% \mathrm{~N})$ as nitrogen fertilizer. All the plots were fertilized with super phosphate and K- sulfate according to the general recommendation dose of Ministry of Agriculture. Wheat seeds were hand sown in $1^{\text {st }}$ December 2014 at the rate of $60 \mathrm{~kg} / \mathrm{fad}$. Nitrogen fertilizer rate was split into three doses: the first dose (20\%) at sowing, the 2 nd dose (40\%) after 25 days from sowing and the $3^{\text {rd }}$ dose $(40 \%)$ after 50 days from sowing. All cultural practices were same for all treatments. Wheat harvested in the last week of May. The plant samples were collected randomly from each treatment and separated to straw and grain. It was dried at $70 \mathrm{C}$ in an oven at a constant weight for 


\section{Effect of different nitrogen levels on some soil characteristics and chemical composition of wheat plant (Triticum aestivium L.)}

determination of N, P and K. Chemical composition, i.e.(crude protein, total carbohydrates, lipid, ash and fiber) were determined by near infra analyzer (NIR), according to Zhao et al. ${ }^{(12)}$. The moisture content was determined according to the proceeding outlined by A.O.A.C. ${ }^{(13)}$. Seed storage protein of two Egyptian Wheat varieties was analyzed using Sodium Dodecyl Sulfate Polyacrylamide Gel Electrophoresis (SDS-PAGE) according to the method of Laemmli ${ }^{(14)}$. The protein gel was scanned and analysis was carried by image analysis software, which was provided from thermo scientific. Soil samples were collected from a depth of $0-20 \mathrm{~cm}$ after harvest, air-dried, crushed and passed through a $2.0 \mathrm{~mm}$ sieve for analysis. The characteristics of the investigated soil, i.e. Particle size distribution, Soil $\mathrm{pH}, \mathrm{EC}$, available $\mathrm{N}, \mathrm{P}$, K, were determined according to Page et al. ${ }^{(15)}$ and $\mathrm{Klute}^{(16)}$. N, P and K were estimated in the plant digest $^{(17)}$. Some physical and chemical properties of the studied soil are presented in Table (1).

Table (1). Some physical and chemical properties of the studied soil.

\begin{tabular}{|c|c|c|c|c|c|c|c|c|c|c|c|c|}
\hline \multirow[t]{2}{*}{ Parameters } & \multirow[t]{2}{*}{$\mathrm{pH}$} & \multirow[t]{2}{*}{$\begin{array}{l}\text { EC } \\
\text { dS.m-1 } \\
(1: 2.5)\end{array}$} & \multirow[t]{2}{*}{$\begin{array}{c}\mathrm{OM} \\
\%\end{array}$} & \multirow[t]{2}{*}{$\begin{array}{c}\text { CEC } \\
\text { meq/100 g } \\
\text { soil }\end{array}$} & \multicolumn{3}{|c|}{ 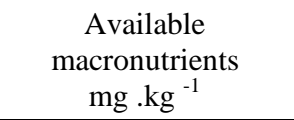 } & \multirow[t]{2}{*}{$\begin{array}{l}\text { Bulk } \\
\text { density } \\
\mathrm{g} / \mathrm{cm}^{3}\end{array}$} & \multicolumn{3}{|c|}{$\begin{array}{c}\text { Particle size distribution } \\
\%\end{array}$} & $\begin{array}{l}\text { Textural } \\
\text { class }\end{array}$ \\
\hline & & & & & $\mathrm{N}$ & $\mathrm{P}$ & $\mathrm{K}$ & & Sand & Silt & Clay & \multirow{2}{*}{$\begin{array}{l}\text { Sandy } \\
\text { clay } \\
\text { loam }\end{array}$} \\
\hline Values & 7.83 & 0.88 & 0.48 & 4.17 & 26.0 & 11.5 & 138.0 & 1.49 & 53.8 & 17.3 & 28.9 & \\
\hline
\end{tabular}

\section{RESULTS AND DISCUSSION}

\section{Effect of different $\mathbf{N}$ application rate on Soil characteristics}

The effect of different $\mathrm{N}$ application rates on soil properties were shown in Table (2). Generally in the two cultivars Gemmeiza 7(G.7) and Gemmeiza 9(G.9) data showed that soil organic matter, EC and soil porosity were increased with increasing the rate of nitrogen application. Improvement in organic matter was due to decomposition of nitrogen sources and increasing $\mathrm{N}$ availability in soil at proper times. These results are identical to the findings of Hao et al. ${ }^{(18)}$. While $\mathrm{pH}$ and the bulk density were decreased. It can be observed that the highest value of organic matter was recorded $(0.9 \%)$ at $260 \mathrm{~kg} / \mathrm{fed}$. While the lowest value recorded $(0.58 \%)$ at control. The values of electrical conductivity (EC) ranged between 1.9 to $1.24 \mathrm{dS} / \mathrm{m}$. In addition to that the soil reaction of the experimental site was ranged between 7.7 and 7.44. The clear trend of decreasing soil $\mathrm{pH}$ was observed with increasing the rate of applied $\mathrm{N}$-fertilizer . These data are in agreement with those obtained by Zhong et $a{ }^{(19)}{ }^{(19)}$ who found that $\mathrm{pH}$ values were decreased by the more $\mathrm{N}$ application. On the other hand bulk density decreased with increasing the rate of nitrogen. The values ranged between $1.52 \mathrm{~g} / \mathrm{cm}^{3}$ and $1.30 \mathrm{~g} / \mathrm{cm}^{3}$. These could attribute to the increasing the root growth, proliferation by the increasing of $\mathrm{N}$-fertilization. 
Abdeen S.A. et al.

Table (2). Some soil properties as affected by the addition of different levels of nitrogen after wheat harvest.

\begin{tabular}{|c|c|c|c|c|c|c|c|c|c|c|}
\hline Characters & \multicolumn{2}{|c|}{ pH } & \multicolumn{2}{|c|}{ EC dS.m ${ }^{-1}$} & \multicolumn{2}{|c|}{ OM \% } & \multicolumn{2}{|c|}{$\begin{array}{c}\text { Bulk density } \\
\mathrm{g} / \mathrm{cm}^{3}\end{array}$} & \multicolumn{2}{|c|}{ Porosity \% } \\
\hline \multirow{2}{*}{$\begin{array}{c}\text { Nitrogen rate } \\
\text { Kg/fed }\end{array}$} & \multicolumn{2}{|c|}{ Cultivars } & \multicolumn{2}{|c|}{ Cultivars } & \multicolumn{2}{|c|}{ Cultivars } & \multicolumn{2}{|c|}{ Cultivars } & \multicolumn{2}{|c|}{ Cultivars } \\
\hline & G.9 & G.7 & G.9 & G.7 & G.9 & G.7 & G.9 & G.7 & G.9 & $\begin{array}{ll}\text { G.7 } \\
\end{array}$ \\
\hline $\mathbf{0}$ & 7.73 & 7.71 & 0.91 & 0.98 & 0.58 & 0.58 & 1.47 & 1.52 & 44.53 & 42.64 \\
\hline 65 & 7.70 & 7.70 & 0.90 & 1.11 & 0.67 & 0.67 & 1.45 & 1.44 & 45.28 & 45.66 \\
\hline 130 & 7.66 & 7.55 & 1.10 & 1.18 & 0.78 & 0.78 & 1.40 & 1.40 & 47.17 & 47.17 \\
\hline 195 & 7.57 & 7.53 & 1.12 & 1.21 & 0.86 & 0.86 & 1.37 & 1.37 & 48.30 & 48.30 \\
\hline 260 & 7.49 & 7.44 & 1.20 & 1.24 & 0.90 & 0.90 & 1.37 & 1.37 & 48.30 & 48.30 \\
\hline Mean & 7.63 & 7.59 & 1.05 & 1.14 & 0.76 & 0.76 & 1.41 & 1.42 & 46.72 & 46.41 \\
\hline $\begin{array}{c}\text { LSD at } 5 \% \\
\text { A } \\
\text { B } \\
\text { AB }\end{array}$ & \multicolumn{2}{|c|}{$\begin{array}{l}0.006 \\
0.011 \\
0.015\end{array}$} & \multicolumn{2}{|c|}{$\begin{array}{l}\text { 0.025 } \\
0.039 \\
0.057\end{array}$} & \multicolumn{2}{|c|}{$\begin{array}{c}\text { N.S } \\
\text { 0.007 } \\
\text { N.S }\end{array}$} & \multicolumn{2}{|c|}{$\begin{array}{c}\text { 0.010 } \\
\text { N.S } \\
\text { 0.005 }\end{array}$} & \multicolumn{2}{|c|}{$\begin{array}{l}\text { N.S } \\
0.69 \\
0.97\end{array}$} \\
\hline
\end{tabular}
G.9=Gemmeiza 9
G.7= Gemmeiza 7
$\mathrm{A}=$ Cultivars
$\mathrm{B}=$ Nitrogen rate

Effect of different $\mathrm{N}$ application rate on $\mathrm{N}, \mathrm{P}$ and $\mathrm{K}$ contents in straw and grain

The data presented in Table (3) clearly showed that a significant effect of nitrogen levels on $\mathrm{NP}$ and $\mathrm{K}$ in the parts of wheat plant (straw and grain). Generally, application of $260 \mathrm{~kg} \mathrm{~N} / \mathrm{fed}$ gave the highest values of NP and K contents in straw and grain compared as control treatment. The addition of $195 \mathrm{Kg} / \mathrm{fed}$ gave the highest values of $\mathrm{p}$ in grains in the two cultivars. This increment might be attributed to the favorable role of nitrogen in encouraging metabolic processes in wheat plants. Similar finding has been reported by Abdel-Hameed ${ }^{(20)}$.

Concerning the effect of nitrogen rates on wheat grains, data in Table (3) showed that application rates of nitrogen increased $\mathrm{N} \mathrm{P}$ and $\mathrm{K}$ percentages in wheat grains compared with control. The increasing on $\mathrm{N}$ was significantly .These could attribute to the increasing the root growth, proliferation with the increased $\mathrm{N}$-fertilization. Also, the ability of wheat plants supplied with $\mathrm{N}$-fertilizer in building metabolites, which may contribute much to the increase in dry matter accumulation in growth and consequently increasing nutrient contents.

Table (3). NPK content (\%) in straw and grain in wheat plant as affected by nitrogen rates

\begin{tabular}{|c|c|c|c|c|c|c|c|c|c|c|c|c|}
\hline \multirow{2}{*}{ Characters } & \multicolumn{6}{|c|}{ Straw yield } & \multicolumn{6}{|c|}{ Grain yield } \\
\hline & \multicolumn{2}{|c|}{$\mathbf{N}$} & \multirow{2}{*}{\multicolumn{2}{|c|}{$\frac{\mathbf{P}}{\text { Cultivars }}$}} & \multicolumn{2}{|c|}{$\mathbf{K}$} & \multicolumn{2}{|c|}{$\mathbf{N}$} & \multirow{2}{*}{\multicolumn{2}{|c|}{$\frac{\mathbf{P}}{\text { Cultivars }}$}} & \multicolumn{2}{|c|}{$\mathbf{K}$} \\
\hline \multirow{2}{*}{$\begin{array}{c}\text { Nitrogen rate } \\
\text { Kg/fed }\end{array}$} & \multicolumn{2}{|c|}{ Cultivars } & & & \multicolumn{2}{|c|}{ Cultivars } & \multicolumn{2}{|c|}{ Cultivars } & & & \multicolumn{2}{|c|}{ Cultivars } \\
\hline & G.9 & G.7 & G.9 & G.7 & G.9 & G.7 & G.9 & G.7 & G.9 & G.7 & G.9 & G.7 \\
\hline 0 & 0.91 & 1.10 & 0.14 & 0.13 & 1.11 & 1.24 & 1.76 & 2.33 & 0.23 & 0.25 & 0.60 & 0.71 \\
\hline 65 & 0.96 & 1.23 & 0.13 & 0.15 & 1.10 & 1.37 & 1.98 & 2.45 & 0.25 & 0.22 & 0.63 & 0.76 \\
\hline 130 & 1.60 & 1.64 & 0.16 & 0.18 & 1.30 & 1.49 & 2.40 & 2.60 & 0.29 & 0.28 & 0.63 & 0.79 \\
\hline 195 & 1.67 & 1.83 & 0.18 & 0.18 & 1.30 & 1.53 & 2.63 & 2.75 & 0.31 & 0.32 & 0.67 & 0.88 \\
\hline 260 & 1.70 & 1.92 & 0.18 & 0.20 & 1.36 & 1.55 & 2.70 & 2.90 & 0.31 & 0.30 & 0.68 & 0.90 \\
\hline Mean & 1.37 & 1.54 & 0.16 & 0.17 & 1.24 & 1.44 & 2.29 & 2.54 & 0.28 & 0.27 & 0.64 & 0.81 \\
\hline LSD at $5 \%$ & \multirow{4}{*}{\multicolumn{2}{|c|}{$\begin{array}{l}\mathbf{0 . 0 3 7} \\
\mathbf{0 . 0 5 8}\end{array}$}} & \multirow{2}{*}{\multicolumn{2}{|c|}{0.008}} & \multirow{2}{*}{\multicolumn{2}{|c|}{0.035}} & \multirow{2}{*}{\multicolumn{2}{|c|}{0.154}} & \multirow{2}{*}{\multicolumn{2}{|c|}{ N.S }} & & \\
\hline A & & & & & & & & & & & \multicolumn{2}{|c|}{0.024} \\
\hline B & & & \multirow{2}{*}{\multicolumn{2}{|c|}{0.017}} & & & \multirow{2}{*}{\multicolumn{2}{|c|}{0.353}} & & & & \\
\hline $\mathbf{A B}$ & & & & & \multicolumn{2}{|c|}{ N.S } & & & \multicolumn{2}{|c|}{0.023} & \multicolumn{2}{|c|}{0.053} \\
\hline
\end{tabular}

G.9=Gemmeiza 9 G.7= Gemmeiza $7 \quad \mathrm{~A}=$ Cultivars $\quad \mathrm{B}=$ Nitrogen rate 


\section{Effect of different nitrogen levels on some soil characteristics and chemical composition of wheat plant (Triticum aestivium L.)}

These results are in agreement with those obtained by Zedan et al. ${ }^{(21)}$. The concentration of $\mathrm{N} \mathrm{P}$ and $\mathrm{K}$ in wheat straw and grain in Gemmeiza $9\left(\mathrm{G}_{9}\right)$ varied according to the amount of $\mathrm{N}$ applied in soil. The maximum $\mathrm{N}$ concentration in straw and grains were 1.7 and $2.7 \%$, respectively, when the crop was supplied with $260 \mathrm{~kg} \mathrm{~N} /$ fed., compared with control which recorded the lowest values $(0.91$ and $1.76 \%)$, respectively. In this concern Haileselassie $e t$ al. ${ }^{(22)}$ found grain nitrogen contents of wheat were highest at the highest dose of nitrogen rate $(138 \mathrm{~kg}$ $\mathrm{N} / \mathrm{ha}$ ). On the other hand the highest value of $\mathrm{p}$ content in straw and recorded $0.18 \%$ at 260 $\mathrm{Kg} / \mathrm{fed}$., compared with control which recorded $0.14 \%$. In addition to the highest value of $\mathrm{p}$ content in grain and recorded $0.31 \%$ at $195 \mathrm{Kg} /$ fed., compared with control which recorded $0.23 \%$.

Concerning of the concentration of $\mathrm{K}$ in straw and grain the data showed that, the highest values were recorded 1.36 and $0.68 \%$ respectively at $260 \mathrm{Kg} / \mathrm{fed}$., while the lowest values were recorded in control. These results are in conformity with Abdel-Samad ${ }^{(23)}$ who observed that nitrogen percentage of the grain was increased significantly with increasing the amount of nitrogen fertilizer. Also who found that the percentage of the grain nitrogen content increased from $1.52 \%$ and $1.43 \%$ at zero nitrogen level to $1.77 \%$ and 1.76 at $60 \mathrm{~kg} \mathrm{~N} . \mathrm{ha}^{-1}$ for the first and second seasons, respectively.

Regarding to the effect of nitrogen on NP and K content in Gemmeiza $7\left(\mathrm{G}_{7}\right)$ the data presented in Table (3) cleared that the highest value of $\mathrm{N}$ content in straw and grain recorded 1.92 and $2.90 \%$, respectively at $260 \mathrm{~kg} \mathrm{~N} /$ fed., compared with control which recorded 1.1 and $2.33 \%$ respectively. Also the data showed that the highest values of $\mathrm{P}$ content in straw were recorded 0.2 at $260 \mathrm{Kg} / \mathrm{fed}$. But the highest value of $\mathrm{P}$ concentration in grain was recorded 0.32 at $195 \mathrm{Kg} / \mathrm{fed}$., compared with control. In addition to the highest values of $\mathrm{K}$ in straw and grain recorded 1.55 and $0.9 \%$, respectively at $260 \mathrm{Kg} / \mathrm{fed}$., compared with control which recorded 1.24 and 0.71 , respectively. The similar data were observed by Khan et al. ${ }^{(24)}$ who found that macro nutrients contents were influenced significantly by the application of $\mathrm{N}$. Also, the highest biological yield was recorded with the highest dose of nitrogen application $\left(180 \mathrm{~kg} \mathrm{~N} \mathrm{ha}{ }^{-1 .}\right)$.

\section{Chemical composition of wheat plants as affected by nitrogen rates}

The chemical composition of wheat plants (crude protein, total carbohydrates, lipid, moisture, ash and fiber) were influenced with the addition of nitrogen levels. As shown in Table 4 the data showed that crude protein percentage was significantly increased by increasing the application rate of nitrogen. Generally the percentage of protein in Gemmeiza 7 was higher than Gemmeiza 9 at the same dose of nitrogen. The values of protein content were ranged from (10.98 to 16.39) and (14.54 to 17.03) in (Gemmeiza 9 and Gemmeiza 7), respectively. Similar results

were reported by Abdallah et al. ${ }^{(25)}$. Total carbohydrate was significantly decreased with increasing the rate of nitrogen. The values ranged from (75.11- 69.01) and (71.67-68.79) in (Gemmeiza 9 and Gemmeiza 7), respectively. These results are agreement with Tranaviciene ${ }^{(26)}$ who reported that the concentration of starch was reducing with increasing the rate of nitrogen. Concerning the effect of nitrogen levels on moisture contents (\%) in two verities Gemmeiza 9 and Gemmeiza 7 the data showed that the moisture absorption by wheat flour was varied; the 


\section{Abdeen S.A. et al.}

highest value of moisture was 9.2 in Gemmeiza 9 at $65 \mathrm{Kg} / \mathrm{fed}$ of $\mathrm{N}$ dose ,while, the lowest value was 7.91 in Gemmeiza 7 at control. These results are comparable with Davies et al. ${ }^{(27)}$. Also, the data showed that the increasing of nitrogen doses were decreased the ash contents of varieties under study. Two wheat varieties exhibited highest ash contents at zero nitrogen level. Gemmeiza7 had the highest ash content at control condition and the lowest value was recorded at $260 \mathrm{Kg} / \mathrm{fed}$ of nitrogen.

Table (4). Chemical composition of wheat grains as affected by application of nitrogen levels..

\begin{tabular}{|c|c|c|c|c|c|c|c|c|c|c|c|c|}
\hline Characters & \multicolumn{2}{|c|}{$\begin{array}{c}\text { Crude protein } \\
\%\end{array}$} & \multicolumn{2}{|c|}{$\begin{array}{c}\text { Total } \\
\text { carbohydrate \% }\end{array}$} & \multicolumn{2}{|c|}{$\begin{array}{l}\text { Lipids } \\
\text { ( L)\% }\end{array}$} & \multicolumn{2}{|c|}{$\begin{array}{c}\text { Moisture } \\
\%\end{array}$} & \multicolumn{2}{|c|}{ Fiber \% } & \multicolumn{2}{|c|}{ Ash \% } \\
\hline \multirow{2}{*}{$\begin{array}{c}\text { Nitrogen rate } \\
\mathrm{Kg} / \mathrm{fed}\end{array}$} & \multicolumn{2}{|c|}{ Varieties } & \multicolumn{2}{|c|}{ Varieties } & \multicolumn{2}{|c|}{ Varieties } & \multicolumn{2}{|c|}{ Varieties } & \multicolumn{2}{|c|}{ Varieties } & \multicolumn{2}{|c|}{ Varieties } \\
\hline & G.9 & G.7 & G.9 & G.7 & G.9 & G.7 & G.9 & G.7 & G.9 & G.7 & G.9 & G.7 \\
\hline 0 & 10.98 & 14.54 & 75.11 & 71.67 & 1.53 & 1.55 & 8.41 & 7.91 & 2.61 & 3.36 & 1.36 & 1.77 \\
\hline 65 & 13.30 & 15.27 & 71.98 & 70.21 & 1.58 & 1.13 & 9.20 & 8.89 & 2.69 & 3.39 & 1.25 & 1.11 \\
\hline 130 & $\begin{array}{l}15.60 \\
\end{array}$ & 15.76 & 70.21 & 70.23 & 1.38 & 1.57 & 8.28 & 8.21 & 3.36 & 3.36 & 1.17 & 1.08 \\
\hline 195 & 15.69 & 16.35 & 70.80 & 69.35 & 1.33 & 1.48 & 8.06 & 8.39 & 3.04 & 3.39 & 1.08 & 1.04 \\
\hline 260 & 16.39 & 17.03 & 69.01 & 68.79 & 1.44 & 1.55 & 8.84 & 8.06 & 3.30 & 3.78 & 1.02 & 0.79 \\
\hline Mean & 14.39 & 15.79 & 15.09 & 71.42 & 70.05 & 70.74 & 1.45 & 1.46 & 1.45 & 8.86 & 8.29 & 8.43 \\
\hline LSD at $5 \%$ & \multirow{2}{*}{\multicolumn{2}{|c|}{0.72}} & \multirow{2}{*}{\multicolumn{2}{|c|}{0.37}} & \multirow{2}{*}{\multicolumn{2}{|c|}{ N.S }} & \multirow{2}{*}{\multicolumn{2}{|c|}{ N.S }} & \multirow{2}{*}{\multicolumn{2}{|c|}{0.24}} & \multirow{2}{*}{\multicolumn{2}{|c|}{0.007}} \\
\hline A & & & & & & & & & & & & \\
\hline B & \multirow{2}{*}{\multicolumn{2}{|c|}{1.14}} & & \multirow{2}{*}{\multicolumn{2}{|c|}{0.013}} & & & \multirow{2}{*}{\multicolumn{2}{|c|}{$\begin{array}{l}0.38 \\
\text { N.S }\end{array}$}} & \multirow{2}{*}{\multicolumn{2}{|c|}{$\begin{array}{l}0.011 \\
0.014\end{array}$}} \\
\hline $\mathbf{A B}$ & & 1.62 & & & & & \multicolumn{2}{|c|}{ N.S } & & & & \\
\hline
\end{tabular}

Total seed storage Protein by using Electrophoretic analysis as affected by nitrogen rates

Generally, data in table 5 illustrated that there are ten polymorphic bands were detected with molecular weight ranging from 180.97 to $7.28 \mathrm{KD}$, these bands are distributed along the gel in a range of $\mathrm{Rf} 0.318$ to 0.984 , it can be observed that there is a variation in the number of bands between the studied genotypes. Gemmeiza9 had 6 bands in a control, 65, 130 and $195 \mathrm{Kg} / \mathrm{fed}$ of $\mathrm{N}$, while it had 8 bands at $260 \mathrm{Kg} / \mathrm{fed}$ of $\mathrm{N}$. Gemmeiza9 had only a Band of molecular weight 180.97 with Rf 0.318 in treatment with $260 \mathrm{Kg} / \mathrm{fed}$, while in Gemmeiza7 it was found in all of the treatments. Molecular weight with 160.14 at $\mathrm{Rf} 0.343$ and 99.28 at $\mathrm{Rf} 0.442$ were presented in all of treatments except the control condition in Gemmeiza 9, while in Gemmeiza7 had not found at the same level of previous molecular weight in all of the treatments. Gemmeiza7 and Gemmeiza 9 had protein bands of molecular weight at $28.26 \mathrm{KD}$ with $\mathrm{Rf} 0.703$ and $7.28 \mathrm{KD}$ with $\mathrm{Rf} 0.984$ in all of the treatments. In general, the number of total band increased with increasing of dose of Nitrogen fertilization about controlled treatments. In this concern Woyema et $a{ }^{(28)}$ ) found that the nitrogen rates had a significant effect on yield and protein content in some wheat cultivars. 


\section{Effect of different nitrogen levels on some soil characteristics and chemical composition of wheat plant (Triticum aestivium $L$.)}

Table (5). Total storage protein for two Egyptian wheat varieties by using Electrophoretic analysis as affected by nitrogen rates.

\begin{tabular}{|c|c|c|c|c|c|c|c|c|c|c|c|}
\hline \multirow{3}{*}{ MW } & \multirow{3}{*}{ RF } & \multicolumn{10}{|c|}{ Kg/fed of N } \\
\hline & & \multicolumn{5}{|c|}{ Gemmeiz 9} & \multicolumn{5}{|c|}{ Gemmeiza7 } \\
\hline & & 0 & 65 & 130 & 195 & 260 & $\mathbf{0}$ & 65 & 130 & 195 & 260 \\
\hline 180.97 & 0.318 & - & - & - & - & + & + & + & + & + & + \\
\hline 160.14 & 0.343 & - & + & + & + & + & - & - & - & - & - \\
\hline 144.89 & 0.364 & + & - & - & + & - & - & + & + & + & + \\
\hline 129.64 & 0.387 & + & + & + & - & - & + & + & + & + & + \\
\hline 99.28 & 0.442 & - & + & + & + & + & - & - & - & - & - \\
\hline 76.03 & 0.498 & + & - & - & - & + & - & - & - & + & + \\
\hline 55.69 & 0.562 & - & - & - & - & + & + & + & + & + & + \\
\hline 46.61 & 0.599 & + & + & + & + & + & - & - & - & + & + \\
\hline 28.26 & 0.703 & + & + & + & + & + & + & + & + & + & + \\
\hline 7.28 & 0.984 & + & + & + & + & + & + & + & + & + & + \\
\hline
\end{tabular}

$\mathrm{MW}=$ molecular weight $\mathrm{RF}=$ relative flow $(+)$ means presence $\quad(-)$ means absence of band

\section{Conclusion}

Generally, it can be concluded that soil organic matter, EC and soil porosity were increased with increasing the rate of nitrogen application. But $\mathrm{pH}$ and the bulk density were decreased. This is true for all the studied cultivars (Gemmeiza 7 and Gemmeiza 9). Also the positive effect of nitrogen levels on NP and $\mathrm{K}$ in the parts of wheat plant (straw and grain) were recorded. Application of $260 \mathrm{~kg} \mathrm{~N} /$ fed gave the highest values of $\mathrm{N}$ and $\mathrm{K}$ contents in straw and grain compared with control. In addition that the highest value of p observed at $195 \mathrm{Kg} / \mathrm{fed}$., especially in grains. On the other hand, chemical composition of wheat varieties was affected by the addition of nitrogen rates. Lipids and total carbohydrate were decreased with increasing the rate of nitrogen. Fiber was increased and total number band of Protein electrophoretic increased with increasing the nitrogen levels compared with control. Generally, Protein percentage in Gemmeiza 7 was higher than Gemmeiza at the same doses of nitrogen.

\section{REFERENCES}

1- Teklu, E. and Hailemariam, T. (2009). Agronomic and economic efficiency of manure and urea fertilizers use on vertisols in Ethiopian highlands. J. Agri. Sci., 8(3): 352-360.

2- Ibrahim,Y.M. and Kittani, H.F. (2009). Effect of different doses of Nitrogen Fertilization on productivity of Durum Wheat Cultivars : A multivariate Approach. J. Sci. and Tech., 10(3): 77-84.

3- Mahmud, K.; Ahmad, I. and Ayub, M. (2003). Effect of nitrogen and phosphorus on the 34 fodder yield and quality of two sorghum (Sorghum bicolor L.). Int. J.Agric. Biol., 5: 61-63.

4- Gooding, M.J. and W.P. Davies (1997). The production and utilization of wheat, system, quality and the environment, $352 \mathrm{pp}$. Oxford. CAB International, Wallingford, U.K.

5- Koriem, M.H.M., (2008) Response of some wheat cultivars to nitrogen and biofertilization. $\mathrm{Ph}$. D. Thesis, Fac. Agric. Kafr El-Sheikh, Univ. Egypt.

6- Semenov, M.A.; P.D. Jamieson and P. Martre. (2007). Deconvoluting nitrogen use efficiency in wheat: A simulation study. Eur. J. Agron., 26:283-294. 


\section{Abdeen S.A. et al.}

7- Zaki, N.M.; M.A. Gomaa; F.I. Radwan; M.S. Hassanein and A.M. Wali (2012). Effect of mineral organic and bio-fertilizer on yield, yield components and chemical composition of some wheat cultivars. J. Applied Sci., Res., 8(1): 174-191.

8- Iqtidar, H.; Muhammad, A.K. and Ejaz, A.K. (2006). Bread wheat varieties as influenced by different nitrogen levels. J. Zhejiang Univ. Sci. 7(1): 70-78.

9- Tilman, D.; Cassman, K.G.; Matson, P.A.; Naylor, R. and Polasky, S. (2002). Agricultural sustainability and intensive production practices. Nature. 418: 671-677.

10- Walch-Liu, P.; Neumann, G.; Bangerth, F. and Engels, C. (2000). Rapid effects of nitrogen form on leaf morphogenesis in tobacco. J.Exper. Bot., 51:227-237.

11- Canfield, D.E.; Glazer, A.N. and Falkowski, P.G. (2010). The Evolution and Future of Earth's Nitrogen $\quad$ Cycle. $\quad$ Science, $330, \quad 192-196$. http://dx.doi.org/10.1126/science.1186120.

12- Zhao, C.; Liu, L.; Wang, J.; Huang, W.; Song, X. and Li, C. (2005). Predicting grain protein content of winter wheat using remote sensing data based on nitrogen status and water stress. Int. J. Appl. Earth Observation and Geoinformation., 7(1): 1-9.

13- A.O.A.C. (1990). Official Methods of Analysis of the Association of Official Agriculture Chemists. $15^{\text {th }}$ ed. Washington D.C., U.S.A.

14- Laemmli, U.K. (1970). Cleavage of structure protein during assembly of the head bacteriophage T4. Nature, 227:680- 685.

15- Page, A.L.; Miller, R.H. and Keeny, D.R. (1982). Methods of Soil Analysis. Part П. Chemical and microbiological properties $2^{\text {nd }}$ Ed., Amer. Soc. Agron. Monograph No. 9 Madison, Wisconsin,USA.

16- Klute, A. (1986). Methods of Soil Analysis. Part 1. Physical and mineralogical Methods $2^{\text {nd }}$ Ed., Amer. Soc. Agron. Monograph No. 9 Madison,Wisconsin,USA.

17- Cottenie, A.; Verloo, M.; Velghe, G. and Comerlynk, R. (1982). Chemical analysis of plant and soil. Laboratory of analytical and Agro-chemistry State University, Ghent, Belgium.

18- Hao, S. Dond; C.H. Hu; K. Wang; J. Zhang and P. Liu. (2002). Effect of organic manure and inorganic fertilizer on kernel yield of maize and top soil chracterstics. Int. J. of Agro., $12(3): 100-102$.

19- Zhong, H.; Wang, Q.; Zhao, X.; Du, Q.; Zhao,Y.; Wang, X.; Jiang, C.; Zhao, S.; Cao, M.; $\mathrm{Yu}, \mathrm{H}$., and Wang, D. (2014). Effects of different nitrogen applications on soil physical, chemical properties and yield in maize (Zea mays L.). Agric. Sci., 5:1440-1447.

20- Abdel-Hameed, I.M. (2005). Response of two newly released bread wheat cultivars to different nitrogen and phosphorus levels. Alex. J. Agric. Res., 50(2B): 63-77.

21- Zedan, E. M.; I. M. Abdel-Hameed; A.M. Bassiouny and A. A. Waly (2009). Effect of irrigation intervals, nitrogen and organic fertilization on yield, yield attributes and crude protein content of some wheat cultivars under newly reclaimed saline soil conditions. $1^{\text {st }}$ conf. On Recent technology to Agriculture.

22- Haileselassie, B.; Habte, D.; Haileselassie, M. and Gebremeske, G. (2014). Effects of mineral nitrogen and phosphorus fertilizers on yield and nutrient utilization of bread wheat (Tritcum aestivum) on the sandy soils of Hawzen District, Northern Ethiopia. Agric. Forestry and Fish., 3(3): 189-198.

23- Abdel-Samad, H.A. (2004). Effect of nitrogen levels and sowing date on growth and yield of wheat (Triticum aestivium L.) varieties grown at different elevations in Jebel Marra highland. M.Sc.Thesis. Fac. of Faculty of Agriculture Khartoum Univ. 


\section{Effect of different nitrogen levels on some soil characteristics and chemical composition of wheat plant (Triticum aestivium $L$.)}

24- Khan, P.; Imtiaz, M.; Aslam, M.; Shah, S.H.; Memon, N. and Siddiqui, S. (2008). Effect of different nitrogen and phosphorus ratios on the performance of wheat cultivar KHIRMAN. Sarhad J. Agric. 24(2).

25- Abdallah, A.M.; Gamalat, O. Mahmoud; Sawsan, A. El-Ssadi and Hanaa F.Y. Mohamed (2013). Wheat production and plant chemical composition under different mineral and biofertilizer treatments. 2013J. Plant Production, Mansoura Univ., 4 (7): 1119-1137.

26- Tranaviciene, T., Siksnianienė, J. B., Urbonaviciute, A., Vaguseviciene, I., Samuoliene, G., Duchovskis, P., \& Sliesaravicius, A. (2007). Effects of nitrogen fertilizers on wheat photosynthetic pigment and carbohydrate contents. Biologija, 53(4), 84-88.

27- Davis, K.R.; Cain, R.F.; Peters, L.J.; Le Tourneau, D. and McGinnis, J. (1981). Evaluation of the nutrient composition of wheat. II. Proximate analysis, thiamin, riboflavin, niacin, and pyridoxine [Varieties from 49 growing locations]. Cereal Chemistry, 48: 116.

28- Woyema, A.; Bultosa, G. and Taa, A. (2012). Effect of different nitrogen fertilizer rates on yield and yield related traits for seven durum wheat (Triticum turgidum L. var Durum) cultivars grown at Sinana, South Eastern Ethiopia. Afr. J. Food, Agric.Nutr. and Develop., 12(3):6079-6094.

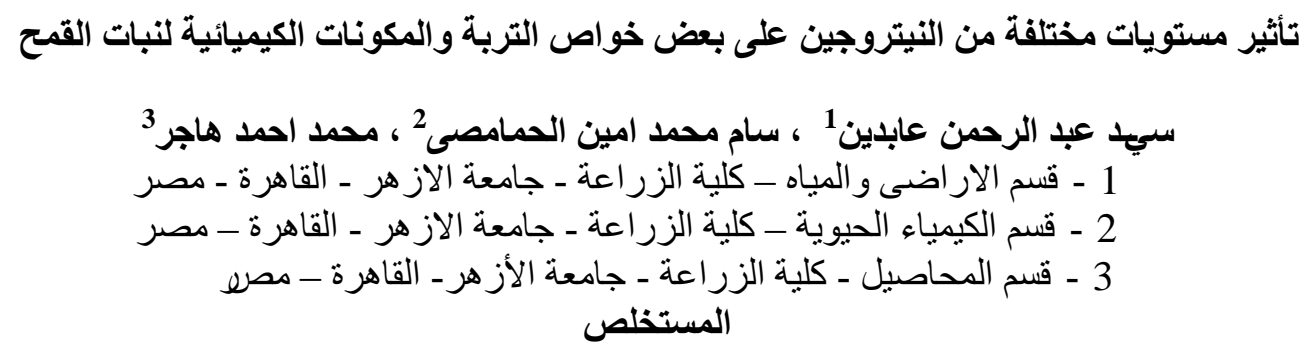

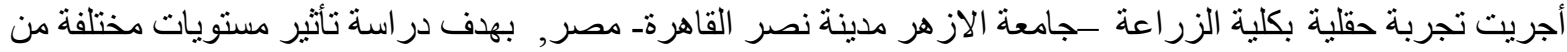

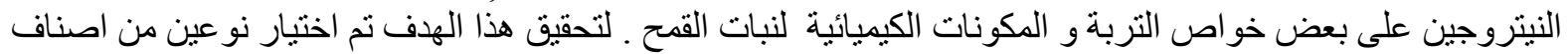

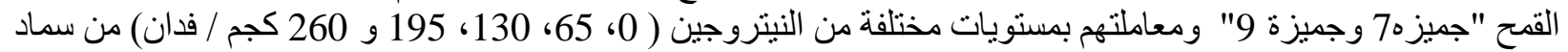
اليوريا (46\% نيتروجين) ـ تم معاملة جميع المعاملات بالسوبر فوسفات وكبريتات البوتاسيوم طبقا للتوصية السمادية لوز لوارة

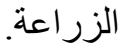

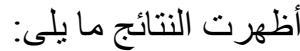
- زيادة قيم المواد العضوية في التربة،التركيز الكلى للاملاح ومسامية التربة مع زيادة معدلات النتروجين.

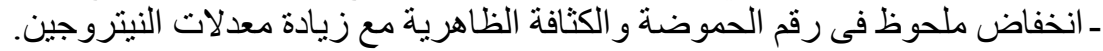

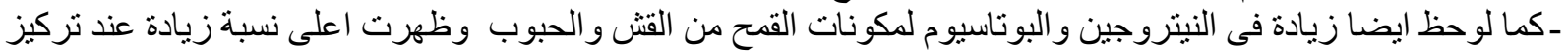

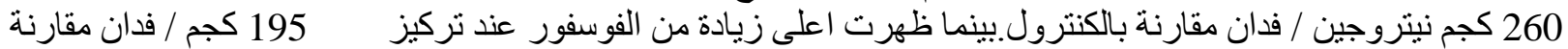

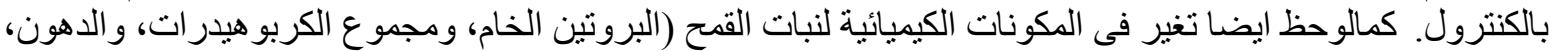

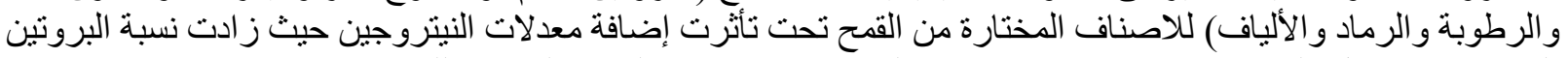

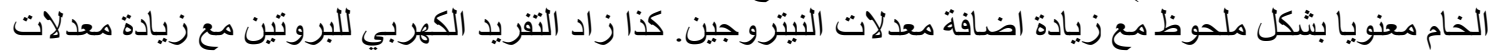

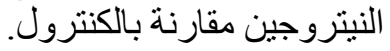

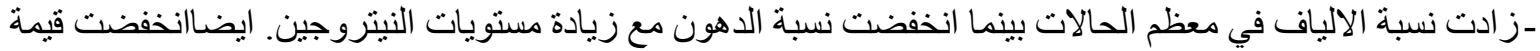

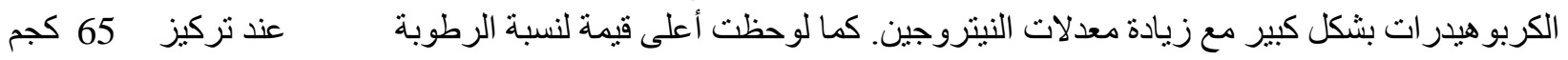

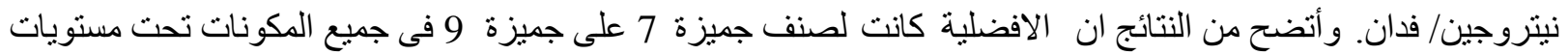
النيتروجين المختلفة. 